\title{
Impact of Technological Interventions on Productivity of Mustard in Kymore Plateau and Satpura Hills Zone of Madhya Pradesh
}

\author{
Jai Singh $^{1}$, A.K. Singh ${ }^{2 *}$, A.K. Chaubey ${ }^{1}$ and M.S. Baghel ${ }^{1}$ \\ ${ }^{1} J N K V V$ Krishi Vigyan Kendra, Sidhi -486661, M.P., India \\ ${ }^{2}$ Krishi Vigyan Kendra, JNKVV, Jabalpur-482004, M.P., India \\ *Corresponding author
}

\section{Keywords}

Indian mustard, Technology Frontline demonstrations, Extension gap, Technology gap, Technology index, $\mathrm{B}: \mathrm{C}$ ratio

Article Info

Accepted:

20 January 2019

Available Online:

10 February 2019

\section{A B S T R A C T}

India is the fourth largest oilseed producer in the world. Among the edible oilseed crops cultivated in India, mustard occupying the second position after groundnut sharing 27.5 per cent in Indian economy. It is also one of the important oilseed crops of Madhya Pradesh and is commonly grown in Sidhi district which falls in Kymore Plateau and Satpura Hills zone of the state. Krishi Vigyan Kendra, Sidhi conducted 64 technological frontline demonstrations to know the yield gap between improved package of practices (IP) and farmers practices (FP) under limited irrigation conditions. The study revealed that the mustard yield in improved practice ranged from 8.75 to $13.23 \mathrm{q} / \mathrm{ha}$ whereas in farmers practice it was in range of 6.70 to $10.09 \mathrm{q} / \mathrm{ha}$. The technology demonstration on mustard registered highest yield $(13.23 \mathrm{q} / \mathrm{ha})$ which recorded in 2014-15 in which was 31.11 per cent higher over the farmer's practice $(10.09 \mathrm{q} / \mathrm{ha})$. Extension gap and technology gap ranged between 1.87 to 3.60 and 2.95 to 11.43 q/ha respectively. The technology index ranged from 19.66 per cent to 57.15 per cent. The technology gap and index reflected farmer's collaboration in carrying out the technology demonstrations with encouraging results in preceding years. The benefit cost ratio was estimated to be 2.15 to 3.64 under demonstration, while it ranged from 1.91 to 2.85 under farmer's practice. The results indicated that these technology frontline demonstrations produced good impact on the farming community of the district as they were motivated by the technological interventions applied for considerably better production of mustard.

\section{Introduction}

Oilseed constitutes the second largest agricultural commodity in India after cereals accounting for nearly 5 per cent of gross national product and 10 per cent of the value of all agricultural products. Despite the fact that India is one of the leading oilseed producing countries in the world, it is not able to meet the edible oil requirement for its own vast population. Among the oilseeds, mustard is an important oilseed crop of India standing next to groundnut in terms of both area and production. India is one of the largest producer of rapeseed - mustard in the world and contribute 19.29 per cent and 11.18 percent of total area and production respectively (USDA, 2012) but the average National productivity remains $1184 \mathrm{~kg} / \mathrm{ha}$ which is far below the world average 1950 
$\mathrm{kg} / \mathrm{ha}$. Its area of the country is 5.76 million hectare with producing around 6.822 million tonnes (Anonymous, 2016). In Madhya Pradesh, rapeseed and mustard grown in an area of 0.617 million hectare with total production of 0.70 million tones and the average productivity of $1134 \mathrm{~kg} / \mathrm{ha}$ (Anonymous, 2016). The area under mustard is 6.8 thousand hectares in the Sidhi district of Madhya Pradesh. However, average productivity of the district is $677 \mathrm{~kg} / \mathrm{ha}$ which is very low in comparison to that of the state which is $1134 \mathrm{~kg} / \mathrm{ha}$. The low yield of mustard in the Sidhi district are attributed to the non availability of improved cultivars, inadequate dose of fertilizers, non application of secondary plant nutrients, untimely management of diseases and pests etc. Among the various agronomic practices date of sowing, plant spacing, seed treatment, application of biofertilizers and crop management practices play an important role in determining the yield of mustard. Keeping in the view the above, technology frontline demonstrations was conducted by the centre to enhance the production of mustard. The aim of technology frontline demonstrations in general was to raise the production through technology transfer and influence the farmers as well as the extension functionaries. In the above concern the present study was thus designed with the objective to explore the production potential of mustard through the technological interventions under the actual farm situations in the district.

\section{Materials and Methods}

The present study was carried out by the Krishi Vigyan Kendra, Sidhi during rabi, 2009-10 to 2014-15 (six consecutive years) in the farmer field of the randomly selected villages of Sidhi district under Kymore Plateau and Satpura Hills agro climatic zone of Madhya Pradesh. During the study, an area of 26.8 hectare was covered and the individual plot size was kept 0.4 ha under technology frontline demonstrations in participatory mode at 64 farmers of five villages (Hadbado, Mamder, Jhalwar, Chorgarhi and Karwahi) of Sidhi district. Before conducting these demonstrations, farmers were selected through group meeting and specific training was imparted to the selected farmers regarding different aspects of cultivation was followed as suggested by Venkattakumar et al., (2010). In general, the study soils of the experimental site were loam to sandy loam in texture, neutral in reaction ( $\mathrm{pH} 7.0$ to 7.9$)$, low to medium in organic carbon (0.45 to $0.69 \%)$ and available nitrogen (249 to $312 \mathrm{~kg} / \mathrm{ha}$ ), medium in available phosphorus (12.9 to $21.31 \mathrm{~kg} / \mathrm{ha}$ ) and high in Potassium (282.5 to $315.21 \mathrm{~kg} / \mathrm{ha})$. The package of improved technologies included improved variety of mustard i.e. JM 3 sown in 2009, PusaTarak in 2010-11, 2012-13 and 2014-15 and Pusa Agrani in 2011-12 and 2013-14. Seeds treated with metalaxyl @6g $\mathrm{kg}^{-1}$ seed for prevention of seed borne diseases (Chattopadhyay et al., 2003) and inoculated with PSB @ $20 \mathrm{~g} \mathrm{~kg}^{-1}$ for increasing availability of phosphorus to the crop roots. Sowing was done between $15^{\text {th }}$ October to $30^{\text {th }}$ October in every year keeping seed rate of $5 \mathrm{~kg} / \mathrm{ha}$ at $30 \times 15 \mathrm{~cm}$ plant geometry. The recommended dose of NPKS fertilizers were supplied @ 60:40:20:40 kg/ha through DAP, urea, muriate of potash and sulphur dust in each demonstrations. Full dose of fertilizers were applied as basal except $\mathrm{N}$ which was supplemented in two splits. Weed control was done by use of pre-emergence herbicide pendimethalin @ $0.3 \mathrm{~kg}$ a.i. ha ${ }^{-1}$ and once hand weeding at 35 DAS for effective control of weed. To protect the yield losses in the crop from aphid, spray of NSKE @ 5 per cent at $10-15$ aphid/plant stage was done when it were observed. The harvesting was done during first fortnight of March every year. The farmer's practice included use of degenerated seeds of local varieties @ 4-5 kg 
$\mathrm{ha}^{-1}$ and fertilizer doses were $18 \mathrm{~kg} \mathrm{~N}$ and 46 $\mathrm{kg} \mathrm{P} \mathrm{ha}{ }^{-1}$. Entire dose of $\mathrm{N}$ and $\mathrm{P}$ were broadcasted along with seed under mixed cropping of wheat/gram/lentil at time of sowing. Sowing was done by the farmers during second to third week of November every year. No protection measures were taken by the farmers for management of aphid. The seasonal rainfall data (during crop period) was varied from 88.8 to $117.0 \mathrm{~mm}$. Comparison between technology demonstration package and existing practice of mustard is given in table 1 .

The visit of farmers and extension functionaries was organized at the demonstration plots of improved technological interventions to disseminate the massage at large scale. The demonstration farmers were facilitated by regular visit of KVK scientists in performing field operations like sowing, fertilizer application, pest management, weed management, harvesting etc. during the course of training and visits. The output data was collected from both FLD plot as well as farmers practice plot and finally the extension gap, technology gap, technology index along with cost benefit ratio were worked (Samui et al., 2000) as given below:

Extension Gap $(\mathrm{kg} / \mathrm{ha})=($ Yield in improved practices - Yield in farmers practice)

Technology Gap $(\mathrm{kg} / \mathrm{ha})=($ Potential yield Yield in improved practice)

Technology index $(\%)=($ Technology Gap/Potential yield) x 100

\section{Results and Discussion}

\section{Yield}

The result of 64 front line demonstrations conducted during 2009-10 to 2014-15 in 26.8 ha area on farmer field of four villages of Sidhi district under Kymore Plateau and Satpura Hills Agro climatic zone of Madhya Pradesh. The productivity of mustard in Sidhi district of Madhya Pradesh under improved production technology ranged between 857 to $1323 \mathrm{~kg} \mathrm{ha}^{-1}$ with mean seed yield of $1069 \mathrm{~kg}$ $\mathrm{ha}^{-1}$ (Table 3). The productivity of mustard in technology demonstrations ranged from 819 to 972,807 to 953,897 to 1091,907 to 1310 , 1176 to 1488 and 1207 to $1523 \mathrm{~kg} \mathrm{ha}^{-1}$ with an average seed yield of 910, 857, 924, 1195 , 1205 and $1323 \mathrm{~kg} \mathrm{ha}^{-1}$ during 2009-10, 201011, 2011-12, 2012-13, 2013-14 and 2014-15 respectively over the farmer practice seed yield ranged between 695 to $1009 \mathrm{~kg} \mathrm{ha}^{-1}$ with an average of $820.16 \mathrm{~kg} \mathrm{ha}^{-1}$. The additional yield under technological interventions over the farmer's practices ranged from 187 to $360 \mathrm{~kg} \mathrm{ha}^{-1}$ with an average of $248.84 \mathrm{~kg} \mathrm{ha}^{-1}$. An increase of 31.5 $\%, 31.2 \%, 27.44 \%, 43.11 \%, 28.19 \%$, and $31.11 \%$ in productivity of mustard under improved technology demonstrations was noted in 2009-10, 2011-12, 2012-13, 2013-14 and 2014-15 respectively over farmers practice. The increased seed yield with improved production practice was mainly because of increased total dry matter, number of siliquae per plant and harvest index (Table 2). The similar results of yield enhancement in mustard front line demonstrations has been documented by Meena et al., (2012) in Rajasthan. The results are also in confirmatory with the findings of Katare et al., (2011), Dutta (2014) and Ram and Anand (2014).

\section{Yield attributing characters}

The data on yield attributing characters of mustard for six years presented in table 3 revealed that number of siliqua per plant under improved technology demonstrations were $149,159,159,179,156.2$ and 158.33 in comparison to farmers practice (local check) 
which was $112,117,128,121,112$ and 114.7 during 2009-10, 2010-11, 2011-12, 2012-13, 2013-14 and 2014-15 respectively. The increase percentage in number of siliquae per plant under improved production technology was 33.03, 35.89, 24.21, 47.93, 39.46 and 38.03 per cent over the local check (farmers practice).

The average number of siliqua per plant was 160.08 under technology demonstrations and 117.45 under farmers practice, thus there was 36.42 percent more siliqua per plant under technology demonstrations as compared to farmers practice. Meena et al., (2012) and Dutta (2014) were reported that 22.22 to 31.48 percent number siliqua per plant increased in improved production technology in mustard front line demonstrations over farmers practice.

\section{Aphid population}

The data on aphid infestation after spray of NSKE@ @ 0 during the study period is presented in table 3 clearly indicated that during 2009-10, 2010-11, 2011-12, 2012-13, 2013-14 and 2014-15 the per cent aphid infestation under technology demonstrations were $8.5,6.75,11,9.5,8.25$ and 7.0 per cent with an average of 8.5 percent over farmers practice which was $36.75,76.23,63.57,56.3$, 51.5 and 59.5 per cent respectively with an average of 57.33 percent aphid infestation.

The percent reduction in aphid infestation under technology demonstrations during the study years was found to be $74.82,91.14$, $82.69,83.12,83.98$ and 88.23 per cent with an average of 83.99 from 2009-10 to 2014-15. These findings are in conformity with those of Singh and Lal (2009) and Chanchal and Lal (2009) who found that NSKE @ 5\% is effective in reducing the mustard aphid population.

\section{Economic return}

The Economic viability of improved technology over farmers practice was calculated depending on prevailing price of inputs and outputs (Table 4). It was found that the additional cost of production of mustard under technology demonstrations varied from Rs.1250.0 to $1520.90 \mathrm{ha}^{-1}$ with an average of Rs.1352.73 $\mathrm{ha}^{-1}$ over farmer practice which varied from Rs.7092 to $11577.25 \mathrm{ha}^{-1}$ with an average of Rs. $9002.62 \mathrm{ha}^{-1}$. The additional cost incurred in technology demonstrations over farmers practice was mainly due to more cost involved in fertilizer, improved quality seed, seed treatment and IPM measures, However the improved technology resulted in higher net return which ranged from Rs.8695 to $23589.30 \mathrm{ha}^{-1}$ with an average of Rs. $15909.70 \mathrm{ha}^{-1}$ as compared to farmers practice which recorded Rs. 6506 to 17202.7 ha $^{-1}$ with an average of Rs. $10886 \mathrm{ha}^{-1}$. The improved technology demonstrations also gave higher benefit cost ratio $2.52,2.15,2.5,3.64,2.18$ and 2.78 as compared to FP BC ratio 1.91, $1.96,2.29,2.85,2.00$ and 2.55 under farmers practice in the corresponding years from 2009-10 to 2014-15. The additional income could substantially benefit the mustard growers of the region and improved their livelihood too. These results are in conformity with findings of Meena et al., (2012), Dutta (2014) and Sarma et al., (2014) in front line demonstration of rape seed and mustard.

\section{Technology gap}

The technology gap varied between $395-893$ $\mathrm{kg} \mathrm{ha}^{-1}$ (Table 4) at all the locations which proved that encouraging results were obtained in technology demonstrations on account of farmers' cooperation. The variation observed in technology gap may be attributed to the dissimilarity in soil-fertility status and weather condition at different locations. Technology gap was noted to be highest in 
the year 2010-11 (893 $\left.\mathrm{kg} \mathrm{ha}^{-1}\right)$. The similar results of technology gap in rapeseed and mustard crop in front line demonstrations have been recorded by Ram and Anand (2014), Meena et al., (2012), Dutta (2014) and Sarma (2014) who opined that lower the value of technology index, more is the feasibility of the technology demonstrated.

\section{Extension gap}

The highest extension gap of $360 \mathrm{~kg} \mathrm{ha}^{-1}$ and lowest $187 \mathrm{~kg} \mathrm{ha}^{-1}$ was observed in year 2012-13 and 2010-11 respectively (Table 4). This emphasized the need to educate the farmers through various means for the adoption of improved production technologies of mustard to reverse the trend of wide extension gap. More and more use of latest production technologies with high yielding variety will subsequently change this alarming trend of galloping extension gap. The new technologies will eventually lead to the farmers to discontinue the old variety/technology and to adopt new technology. These findings are in corroboration with the findings of Meena $e t$ al., (2012) and Sarma et al., (2014).

\section{Technology index}

The technology index showed the feasibility of the evolved technology for the evaluation at farmers' field and the lower the value of technology index more is the feasibility of the technology (Jeengar et al., 2006). It was found to be ranging between 24.40 to 51.05 per cent and revealed that the lower value of technology index is also feasible rather than the higher value of technology index. The lower value of the technology index of the year of 2014-15 was due to severe attack of aphid. This indicates the yield gap exists between the technology generated at research station and farmers fields. In comparative profitability of mustard the additional benefit cost ratio was obtained in the year 2014-15 (1: 4.2) due to the adoption of recommended mustard production technology (Table 5).

Table.1 Details of technology demonstration package and farmers practice in mustard

\begin{tabular}{|l|l|l|}
\hline Particulars & Demonstration Package & Farmers Practice \\
\hline Variety & JM-3, Pusa Tarak and Pusa Agrani & $\begin{array}{l}\text { Degenerated seeds of varuna } \\
\text { cultivar }\end{array}$ \\
\hline Seed rate & $5 \mathrm{~kg} / \mathrm{ha}$ & $4-5 \mathrm{~kg} / \mathrm{ha}$ \\
\hline $\begin{array}{l}\text { System of } \\
\text { Sowing }\end{array}$ & Sole crop & Mixed with wheat/ gram/lentil \\
\hline Seed treatment & $\begin{array}{l}\text { Metalaxyl @ 6 g/ kg seed + PSB @ 5 } \\
\text { g/kg seed }\end{array}$ & Nil \\
\hline Sowing time & $\begin{array}{l}\text { II fortnight of October } \\
\text { Sowing Methods }\end{array}$ & $\begin{array}{l}\text { Line Sowing at 30X 15 cm spacing } \\
\text { II }- \text { III week of November }\end{array}$ \\
\hline $\begin{array}{l}\text { Farming } \\
\text { Situation }\end{array}$ & $\begin{array}{l}\text { Irrigated (Two irrigation) } \\
\text { NPKS }\end{array}$ & $\begin{array}{l}\text { Rainfed } \\
\text { N 60:40:20:40 kg/ha }\end{array}$ \\
\hline $\begin{array}{l}\text { Insect pest } \\
\text { management }\end{array}$ & $\begin{array}{l}\text { Spray of NSKE @ 5\% at ETL (30 \% } \\
\text { plant affected by aphid) }\end{array}$ & $\begin{array}{l}\text { Spray of Dimethoate @ 1 } \\
\text { ml/litre }\end{array}$ \\
\hline
\end{tabular}


Table.2 Effect of improved production technology on yield of mustard under frontline demonstrations

\begin{tabular}{|l|l|l|l|l|l|l|l|l|}
\hline Year & Variety & $\begin{array}{l}\text { No. of } \\
\text { demo. }\end{array}$ & $\begin{array}{l}\text { Area } \\
\text { (ha) }\end{array}$ & \multicolumn{2}{l}{$\begin{array}{l}\text { Demo yield (kg/ ha) } \\
\text { Highest }\end{array}$} & Lowest & Yverage & \multicolumn{2}{l|}{$\begin{array}{l}\text { Yield of } \\
\text { Local Check } \\
\text { (kg/ ha) }\end{array}$} & $\begin{array}{l}\text { per cent } \\
\text { increase over } \\
\text { local check }\end{array}$ \\
\hline $\mathbf{2 0 0 9 - 1 0}$ & JM-3 & 05 & 2.0 & 972 & 819 & 910 & 695 & 31.5 \\
\hline $\mathbf{2 0 1 0 - 1 1}$ & Pusa Tarak & 12 & 5.0 & 953 & 807 & 857 & 670 & 31.20 \\
\hline $\mathbf{2 0 1 1 - 1 2}$ & Pusa Agrani & 11 & 4.8 & 1091 & 897 & 924 & 725 & 27.44 \\
\hline $\mathbf{2 0 1 2 - 1 3}$ & Pusa Tarak & 12 & 5.0 & 1310 & 907 & 1195 & 835 & 43.11 \\
\hline $\mathbf{2 0 1 3 - 1 4}$ & Pusa Agrani & 12 & 5.0 & 1488 & 1176 & 1205 & 987 & 28.19 \\
\hline $\mathbf{2 0 1 4 - 1 5}$ & Pusa Tarak & 12 & 5.0 & 1523 & 1207 & 1323 & 1009 & 31.11 \\
\hline Total/ Average & $\mathbf{6 4}$ & $\mathbf{2 6 . 8}$ & $\mathbf{1 2 2 2 . 8 3}$ & $\mathbf{9 6 8 . 8 3}$ & $\mathbf{1 0 6 9}$ & $\mathbf{8 2 0 . 1 6}$ & $\mathbf{3 2 . 0 9}$ \\
\hline
\end{tabular}

Table.3 Effect of improved production technology on aphid infestation and yield attributing character of mustard

\begin{tabular}{|c|c|c|c|c|c|c|c|c|c|}
\hline \multirow[t]{2}{*}{ Year } & \multicolumn{2}{|c|}{$\begin{array}{l}\text { Aphid infestation } \\
(\%)\end{array}$} & \multirow{2}{*}{$\begin{array}{l}\% \\
\text { decrease } \\
\text { in aphid } \\
\text { infestation } \\
\text { over } \\
\text { farmers } \\
\text { practice }\end{array}$} & \multicolumn{2}{|c|}{$\begin{array}{l}\text { Incidence of } \\
\text { Alternaria blight } \\
(\%)\end{array}$} & \multirow{2}{*}{$\begin{array}{l}\text { \% decrease in } \\
\text { incidence of } \\
\text { Alterneria blight } \\
\text { over farmers } \\
\text { practice }\end{array}$} & \multicolumn{2}{|c|}{$\begin{array}{l}\text { Yield attributing } \\
\text { Characters (No. of } \\
\text { Siliquae / Plant) }\end{array}$} & \multirow{2}{*}{$\begin{array}{l}\text { \% age } \\
\text { Increase } \\
\text { over } \\
\text { farmers } \\
\text { practice }\end{array}$} \\
\hline & $\begin{array}{l}\text { Improved } \\
\text { Practice }\end{array}$ & $\begin{array}{l}\text { Farmers } \\
\text { Practice }\end{array}$ & & $\begin{array}{l}\text { Improved } \\
\text { Practice }\end{array}$ & $\begin{array}{l}\text { Farmers } \\
\text { Practice }\end{array}$ & & $\begin{array}{l}\text { Improved } \\
\text { Practice }\end{array}$ & $\begin{array}{l}\text { Farmers } \\
\text { Practice }\end{array}$ & \\
\hline 2009-10 & 8.5 & 36.75 & 74.82 & 9.6 & 34.2 & 71.90 & 149 & 112 & 33.03 \\
\hline 2010-11 & 6.75 & 76.23 & 91.14 & 8.9 & 36.12 & 75.35 & 159 & 117 & 35.89 \\
\hline 2011-12 & 11.0 & 63.57 & 82.69 & 10.75 & 31.5 & 65.87 & 159 & 128 & 24.21 \\
\hline 2012-13 & 9.5 & 56.3 & 83.12 & 11.25 & 39.6 & 71.59 & 179 & 121 & 47.93 \\
\hline 2013-14 & 8.25 & 51.5 & 83.98 & 10.5 & 38.12 & 72.45 & 156.2 & 112.0 & 39.46 \\
\hline 2014-15 & 7.0 & 59.5 & 88.23 & 11.5 & 39.5 & 70.88 & 158.33 & 114.7 & 38.03 \\
\hline Average & 8.5 & 57.33 & 83.99 & 10.41 & 36.50 & 71.34 & 160.08 & 117.45 & 36.42 \\
\hline
\end{tabular}

Table.4 Economic impact of improved production technology of mustard under front line demonstrations

\begin{tabular}{|c|c|c|c|c|c|c|c|c|c|}
\hline \multirow[t]{3}{*}{ Year } & \multicolumn{9}{|c|}{ Economics of Mustard Production (Rs./ha) } \\
\hline & \multicolumn{2}{|c|}{$\begin{array}{c}\text { Cost of Cultivation(Rs./ } \\
\text { ha) }\end{array}$} & \multicolumn{2}{|c|}{ Net returns (Rs./ ha) } & \multicolumn{2}{|c|}{$\mathrm{B}: \mathrm{C}$ ratio } & \multirow[t]{2}{*}{$\begin{array}{l}\text { Additional } \\
\text { Cost (q/ha.) }\end{array}$} & \multirow{2}{*}{$\begin{array}{l}\text { Additional } \\
\text { return (Rs./ } \\
\text { ha) }\end{array}$} & \multirow{2}{*}{$\begin{array}{l}\text { Additional } \\
\text { Benefit cost- } \\
\text { ratio }\end{array}$} \\
\hline & $\begin{array}{l}\text { Improved } \\
\text { Practices }\end{array}$ & $\begin{array}{l}\text { Farmers } \\
\text { Practices }\end{array}$ & $\begin{array}{l}\text { Improved } \\
\text { Practices }\end{array}$ & $\begin{array}{l}\text { Farmers } \\
\text { Practices }\end{array}$ & $\begin{array}{l}\text { Improved } \\
\text { Practices }\end{array}$ & $\begin{array}{l}\text { Farmers } \\
\text { Practices }\end{array}$ & & & \\
\hline 2009-10 & 7922.0 & 6692 & 13840.0 & 6506.0 & 2.52 & 1.91 & 1250.0 & 7334.0 & 5.86 \\
\hline 2010-11 & 8005.0 & 6775 & 8695.0 & 6065.0 & 2.15 & 1.96 & 1230.0 & 2630.0 & 2.13 \\
\hline 2011-12 & 7487.5 & 6315.0 & 11292.5 & 8185.0 & 2.57 & 2.29 & 1272.5 & 3107.5 & 2.44 \\
\hline 2012-13 & 8389.0 & 7016.0 & 21686.5 & 15559.0 & 3.64 & 2.85 & 1373.0 & 6127.5 & 4.46 \\
\hline 2013-14 & 12770.0 & 11300 & 16355.0 & 11800 & 2.18 & 2.00 & 1470.0 & 4555.0 & 3.08 \\
\hline 2014-15 & 12589.1 & 11077.2 & 23589.3 & 17202.7 & 2.78 & 2.55 & 1520.9 & 6387.3 & 4.20 \\
\hline Average & 9527.10 & 8195.86 & 15909.71 & 10886.0 & 2.64 & 2.26 & 1352.73 & 5023.58 & 3.71 \\
\hline
\end{tabular}


Table.5 Technology gap, extension gap and technology index in mustard frontline demonstrations

\begin{tabular}{|c|c|c|c|c|c|c|}
\hline Year & $\begin{array}{c}\text { Potential } \\
\text { Yield } \\
\text { (kg/ha) }\end{array}$ & Improved Practices & Farmers Practices & $\begin{array}{c}\text { Technology } \\
\text { gap } \\
\text { (kg/ha) }\end{array}$ & $\begin{array}{c}\text { Extension } \\
\text { gap } \\
\text { (kg/ ha) }\end{array}$ & $\begin{array}{c}\text { Technology } \\
\text { Index (\%) }\end{array}$ \\
\hline $\mathbf{2 0 0 9 - 1 0}$ & 1600 & 910 & 695 & 690.0 & 215 & 43.12 \\
\hline $\mathbf{2 0 1 0 - 1 1}$ & 1750 & 857 & 670 & 893.0 & 187 & 51.05 \\
\hline $\mathbf{2 0 1 1 - 1 2}$ & 1600 & 924 & 725 & 676.0 & 199 & 42.25 \\
\hline $\mathbf{2 0 1 2 - 1 3}$ & 1750 & 1195 & 835 & 555.0 & 360 & 31.71 \\
\hline $\mathbf{2 0 1 3 - 1 4}$ & 1600 & 1205 & 987 & 395.0 & 218 & 24.68 \\
\hline $\mathbf{2 0 1 4 - 1 5}$ & 1750 & 1323 & 1009 & 427 & 314 & 24.40 \\
\hline Average & $\mathbf{1 6 7 5}$ & $\mathbf{1 0 6 9 . 0}$ & $\mathbf{8 2 0 . 1 6}$ & $\mathbf{6 0 6 . 0}$ & $\mathbf{2 4 8 . 8 3}$ & $\mathbf{3 6 . 2 0}$ \\
\hline
\end{tabular}

The Improved production technology of varieties (JM-3/Pusa Tarak/Pusa Agrani) of mustard performed better (average yield 1069 $\mathrm{kg} \mathrm{ha}^{-1}$ ) over the control i.e. farmers' practice (average yield $820.16 \mathrm{~kg} \mathrm{ha}^{-1}$ ) at all the locations under technology demonstrations. From the above findings, conclusion can be drawn that use of improved technology with suitable variety can reduce the yield gap up to a considerable extent leading to increased productivity of mustard crop in the district. Moreover, extension agencies in the district need to provide proper technical guidance and support to the farmers through different educational and extension methods to reduce the extension gap for better mustard production in the district. KVK has also played a major role in serving as a linkage mechanism.

\section{Acknowledgement}

The authors are highly thankful to ICAR for providing financial assistance towards organizing frontline demonstrations of proven technologies; yield potential of mustard thus can be increased to a great extent. This will subsequently increase the income as well as the livelihood for the farming community.

\section{References}

Ahamad, A., Prem, G. and Kumar, R. (2013). Impact of front line demonstrations on Indian mustard through improved technologies. Indian Res. J. Ext. Edu., 13(1)117-119.

Anonymous (2016). Agricultural Statistics at a Glance. Directorate of Economics and Statistics, Department of Agriculture and Cooperation, New Delhi.

Chanchal S and Lal M.N. (2009). Bioefficacy of plant extracts against mustard aphid, Lipaphis erysimi (Kalt.) In: Brassica oilseed crop. Crop Res. 37: 203-206.

Dutta, R. (2014). Yield gap analysis of Rapeseed - Mustard in North Bank Plain Zone of Assam. Indian Res. J. Ext. Edu., 14(3):122-124.

Jeengar, K.L., Panwar, P. and Parrek, O.P. (2006). Front line demonstration on maize in Bhilwara district of Rajsthan. Current Agriculture, 30 (1/2):115-116.

Katare, Subhash; Pandey S.K. and Mustafa, Mohd (2011). Yield gap analysis of Rapeseed- mustard through front line demonstrations. Agric. Update, 6: 5-7.

Meena, B.L., Meena, R.H. and Balai, C.M. 
(2012). Yield gap analysis of rapeseed - mustard through front line demonstrations in agroclimatic zone IVa of Rajasthan. Journal of Oilseed Brassica, 3(1): 51-55.

Ram, Siya and Anand, R.K. (2014). Yield gap analysis of mustard through front line demonstration in district Sonbhadra, U.P. Int. J. Plant Sci., 9 (1): 180-182.

Samui, S.K., Maitra, S., Roy, D.K., Mandal, A.K. and Saha, D. (2000). Evaluation on front line demonstration on groundnut. J. Indian Soc. Cos. Agri. Res., 18(2): 180-183.

Sarma, H., Sarma, R., Sarmah, A.K., Upamanya, G.K. and Kalita, N. (2014). Yield gap analysis of Toria (Brassica compestris) in Barpeta
District of Assam. Indian Res. J. Ext. Edu., 14(2):127-129.

Singh, C.P. and Lal, M. N. (2009). Bioefficacy of plant extract against mustard aphid, Lipaphis erysimi (Kalt.) In: Brassica oilseed crop. Crop Research, 37: 203-206.

USDA. United States Department of Agriculture (2012). Rapeseed-Mustard Nutrient Values and yields. 2012, 114130.

Venkattakumar, R., Ramana, Rao, S.V., Padmaiah, M. and Madhuri, P. (2010). Production constraints and information needs of growers in Andhra Pradesh. Agric. Extn. Review, (April-June): 21-24.

\section{How to cite this article:}

Jai Singh, A.K. Singh, A.K. Chaubey and Baghel, M.S. 2019. Impact of Technological Interventions on Productivity of Mustard in Kymore Plateau and Satpura Hills Zone of Madhya Pradesh. Int.J.Curr.Microbiol.App.Sci. 8(02): 2848-2855. doi: https://doi.org/10.20546/ijcmas.2019.802.334 